Case 3073

\title{
Vespertilio pipistrellus Schreber, 1774 and V.pygmaeus Leach, 1825 (currently Pipistrellus pipistrellus and $P$. pygmaeus; Mammalia, Chiroptera): proposed designation of neotypes
}

\section{Gareth Jones}

School of Biological Sciences, University of Bristol, Woodland Road, Bristol BS81UG, U.K. (e-mail: Gareth.Jones@bristol.ac.uk)

\section{Elizabeth M. Barratt}

Institute of Zoology, Zoological Society of London, Regent's Park, London NW14RY, U.K. (e-mail: Elizabeth.Barratt@ucl.ac.uk)

Abstract. The purpose of this application is to provide neotypes for two broadly sympatric cryptic species of pipistrelle bats; until recently only a single taxon was recognised and known as Pipistrellus pipistrellus (Schreber, 1774). The species were first distinguished by their ultrasonic echolocation calls but also differ in other ways. It is proposed that the species with the lower-pitched call should be denoted by the name $P$. pipistrellus, and that the name $P$. pygmaeus (Leach, 1825), which has been regarded as a synonym of $P$. pipistrellus, should be used for the smaller species which calls at a higher frequency.

Keywords. Nomenclature; taxonomy; Mammalia; Chiroptera; bats; vesPertilionidae; Pipistrellus; Pipistrellus pipistrellus; Pipistrellus pygmaeus.

1. Schreber (1774, p. 167 , pl. 54) described and illustrated a dark brown bat and gave it the name Vespertilio pipistrellus; he cited three earlier works as references for the species, in which it was given the vernacular name 'la pipistrelle'. These were Daubenton (1759, p. 381, pl. 1, fig. 3), Buffon (1760, p. 129, pl. 19, fig. 1) and Pennant (1771, p. 370). Geoffroy Saint-Hilaire (1803, pp. 53-54), also citing Daubenton (1759) and Buffon (1760), noted that at that time there were seven pipistrelle specimens (nos. 113-119) in the Paris Museum, and an additional specimen (no. 120) was a female with young attached to the nipples. Schreber's specific name pipistrellus has been adopted for what is probably the commonest and most widely distributed bat in Europe (see Stebbings \& Griffith, 1986), and the species is the type species by monotypy of the genus Pipistrellus Kaup, 1829 (pp. 98, 188).

2. Leach $(1825$, p. 559 , pl. 22) gave the name Vespertilio pygmaeus to 'a new species' from south-west England. It was noted that this bat 'most nearly resembles the $V$. pipistrellus. But it differs in various particulars. It is ... considerably smaller ... [it is] probable that the smaller Vespertiliones, even in Europe and the neighbouring territories, are not as yet examined with sufficient acccuracy, and that new species, allied to each other in external appearance, remain to be discovered'. A single female specimen formed the basis of the description and is therefore the holotype. In 
October 1824 Leach sent the specimen to one of the 'Conductors of our Journal' (i.e. the Zoological Journal). The four 'conductors' included Dr Thomas Bell, who in 1837 (p. 31) recorded that the 'specimen is now in the British Museum. It is the only one in existence in any collection'. The specimen, currently preserved in the collections of the Mammal Section, The Natural History Museum, London, has never been registered but is listed (no. 61k) in J.E. Gray's 'Manuscript Catalogue of Mammalia, part 1 (Primates and Chiroptera)' as 'Vespertilio pygmaeus Leach, Jl. Zool. Dartmoor, Devon. Prepared by W.E. Leach'; in Gray (1843, p. 29, specimen 61k) as 'Very young, bones of skull not hardened. Zool. Jour. Dartmoor, Devonshire. Presented by W.E. Leach'; and in Dobson (1878, p. 225, specimen d) as 'Immature. Type of Vespertilio pygmaeus Leach. Dartmoor. Presented by W.E. Leach'. The head of the specimen is now separated from the body. At least by 1874 the name $V$. pygmaeus was rejected as a synonym on the assumption (see Bell, 1874, p. 42) that 'there is now no longer any doubt that it [Leach's specimen] is a young Pipistrelle' [i.e. V. pipistrellus]. Examination of the holotype by G. Jones, A. M. Hutson and P. Jenkins has shown that it is indeed an infant female and that the ascertainable measurements conform with those given by Leach $(1825$, p. 560$)$.

3. Pipistrellus pipistrellus (Schreber, 1774) has traditionally been considered to refer to a single biological species and Leach's name pygmaeus has long been treated as a synonym of pipistrellus. However, Jones \& Parijs (1993) showed the existence of two distinct 'phonic types', distinguished by their ultrasonic echolocation calls. The calls emitted by pipistrelles searching for prey consist of pulses lasting $5-10 \mathrm{msec}$; each pulse starts at a high frequency which very rapidly diminishes to a relatively long-lasting 'tail' of almost constant frequency. The calls emitted by bats of the two phonic types were found to have 'tails' with non-overlapping average frequencies of about $46 \mathrm{kHz}$ and $55 \mathrm{kHz}$ respectively. In some geographical areas only one type was found, while in others both occurred together; in the latter cases, however, all the bats belonging to a particular colony were of a single phonic type. Jones \& Parijs (1993) suggested that the two phonic types of $P$. pipistrellus might represent cryptic species. A number of cryptic species are known to exist in other bat genera (see Jones, 1997, p. 336).

4. Subsequently it has been shown that the two types differ not only in acoustic signals but also in overall geographical range (Jones, 1997), habitat (the $55 \mathrm{kHz}$ type preferring riparian sites: Vaughan, Jones \& Harris, 1997), diet (Barlow, 1997), 'social' calls (Barlow \& Jones, 1997a, 1997b) and mating groups (Park, Altringham \& Jones, 1996). The skull morphology shows differences (Barlow, Jones \& Barratt, 1997), but these cannot be used to separate the species with confidence. There are large genetic differences between them (Barratt et al., 1995, 1997): there is a sequence divergence of $11 \%$ in a $630 \mathrm{bp}$ region of the cytochrome $b$ gene of mitochondrial DNA (Barratt et al., 1997). The two types are very similar but not identical in general morphology, and the $55 \mathrm{kHz}$ type is slightly but significantly smaller. There are also subtle but usually recognizable differences in appearance (Jones, 1997, p. 327): the $45 \mathrm{kHz}$ type is darker brown, and it usually has a black face 'mask' while the eyes of the $55 \mathrm{kHz}$ bats are often surrounded by bare skin.

5. The evidence in the papers cited above demonstrates beyond doubt that in Europe there are two reproductively isolated, although often sympatric, cryptic 
species of pipistrelle bats. The name Pipistrellus pipistrellus has covered both, and it is now necessary to be able to apply this name to one of the taxa and another name to the second. The bat illustrated in the original Schreber (1774) plate of $P$. pipistrellus (see para. 1 above) resembles the $45 \mathrm{kHz}$ phonic type (dark brown, shaggy fur, dark face band), and so far only this type has been recorded from France. It would therefore be sensible, if perhaps somewhat arbitrary, to retain the name $P$. pipistrellus for the $45 \mathrm{kHz}$ phonic type. The name $P$. pygmaeus (Leach, 1825: see para. 2 above), which has been considered a synonym of $P$. pipistrellus for more than a century, can be applied to the smaller $55 \mathrm{kHz}$ phonic type. The English vernacular name Common Pipistrelle was used by Corbet \& Hill (1991) for $P$. pipistrellus, and the vernacular name Soprano Pipistrelle is proposed for $P$. pygmaeus because the existence of the cryptic species was first suggested by its high-pitched calls.

6. Some of the supposed synonyms of $P$. pipistrellus listed by Ellerman \& Morrison-Scott (1951, p. 164) may have been based on P. pygmaeus in the sense of the present paper. It is likely that bats referred to as $P$. pipistrellus mediterraneus by Cabrera Latorre (1904) are P. pygmaeus: echolocation work (for example, Kalko, 1995) and molecular studies (Barratt et al., 1997) suggest synonymy with $P$. pygmaeus. We propose the use of the latter name because mediterraneus would be misleading and Leach's name is much older.

7. No original material of Vespertilio pipistrellus Schreber, 1774 is known to exist (see para. 1 above), and even if it does assignment of such old specimens to one or other of the two cryptic species would be difficult and uncertain. Similarly, the holotype of $V$. pygmaeus Leach, 1825 (para. 2 above) is not suitable for demonstrating the differences between the two cryptic species. There is a clear case (in accordance with Recommendation 75E of the 1985 edition of the Code) for neotypes of both nominal species, and we propose that the Commission should set aside any existing type material and designate neotypes for Vespertilio pipistrellus and $V$. pygmaeus; both the specimens mentioned below have been deposited in the Natural History Museum, London, and are accompanied by molecular data confirming their assignment to the two species.

8. The proposed neotype for Vespertilio pipistrellus Schreber, 1774 is registered as specimen no. BMNH 1997.81. It is an alcohol-preserved adult male, forearm length $30.9 \mathrm{~mm}$, collected by R.C. Sabin on 2 October 1996 in Beauvais Cathedral, Normandy, France $\left(49^{\circ} 26^{\prime} \mathrm{N}, 02^{\circ} 05^{\prime} \mathrm{E}\right)$. It is accompanied by a second (dried) specimen registered as BMNH 1997.78. They were found with about 40 others, freshly killed by poisoning by local authority workers.

9. The proposed neotype for Vespertilio pygmaeus Leach, 1825 is registered as specimen no. BMNH 1999.43, deposited 22 April 1999. It is an adult female, weighing $6.9 \mathrm{~g}$ and with forearm length $32.1 \mathrm{~mm}$. It was taken (under licence from English Nature) by Dr G. Jones on 1 October 1998 at Chew Valley Lake, Bath and North East Somerset, southwest England (national grid reference ST 582605, $51^{\circ} 22^{\prime} \mathrm{N}, 02^{\circ} 37^{\prime} \mathrm{W}$ ). It was accompanied by one adult male and one adult female in a mating group in a bat box, and both of these echolocated with peak frequencies close to $55 \mathrm{kHz}$.

10. The International Commission on Zoological Nomenclature is accordingly asked: 
(1) to use its plenary powers to set aside all previous fixations of type specimens for the nominal species Vespertilio pipistrellus Schreber, 1774 and Vespertilio pygmaeus Leach, 1825, and to designate as the respective neotypes the specimens described in paras. 8 and 9 above;

(2) to place on the Official List of Generic Names in Zoology the name Pipistrellus Kaup, 1829 (gender: masculine), type species by monotypy Vespertilio pipistrellus Schreber, 1774;

(3) to place on the Official List of Specific Names in Zoology the following names: (a) pipistrellus Schreber, 1774, as published in the binomen Vespertilio pipistrellus and as defined by the neotype designated in (1) above (specific name of the type species of Pipistrellus Kaup, 1829);

(b) pygmaeus Leach, 1825, as published in the binomen Vespertilio pygmaeus and as defined by the neotype designated in (1) above.

\section{Acknowledgements}

We acknowledge the help of Paula Jenkins and the late J. E. Hill (Department of Zoology, The Natural History Museum, London), Tony Hutson (The Bat Conservation Trust, London) and David Harrison (Harrison Zoological Museum, Sevenoaks, Kent).

\section{References}

Barlow, K.E. 1997. The diets of two phonic types of Pipistrellus pipistrellus (Chiroptera: Vespertilionidae) in Britain. Journal of Zoology, 243: 597-609.

Barlow, K.E. \& Jones, G. 1997a. Differences in songflight calls and social calls between two phonic types of the vespertilionid bat Pipistrellus pipistrellus. Journal of Zoology, 241: 315-324.

Barlow, K.E. \& Jones, G. 1997b. Function of pipistrelle social calls: field data and a playback experiment. Animal Behaviour, 53: 991-999.

Barlow, K.E., Jones, G. \& Barratt, E.M. 1997. Can skull morphology be used to predict ecological relationships between bat species? A test using two cryptic species of pipistrelle. Proceedings of the Royal Society of London, 264B: 1695-1700.

Barratt, E.M., Bruford, M.W., Burland, T.M., Jones, G., Racey, P.A. \& Wayne, R.K. 1995. Characterization of mitochondrial DNA variability within the microchiropteran genus Pipistrellus: approaches and applications. Symposia of the Zoological Society of London, 67: $377-386$.

Barratt, E.M., Deaville, R., Burland, T.M., Bruford, M.W., Jones, G., Racey, P.A. \& Wayne, R.K. 1997. DNA answers the call of pipistrelle bat species. Nature, 387: 138-139.

Bell, T. 1837. A history of British quadrupeds, including the Cetacea. xviii, $526 \mathrm{pp}$. Van Voorst, London.

Bell, T. 1874. A history of British quadrupeds, including the Cetacea, Ed. 2. xviii, 474 pp. Van Voorst, London.

Buffon, G.L.L. de. 1760. Histoire naturelle, générale et particulière, avec la description du Cabinet du Roi, vol. 8. [vi], 402 pp. Imprimerie Royale, Paris.

Cabrera Latorre, A. 1904. Ensayo monográfico sobre los quirópteros de España. Memorias de la Real Sociedad Española de Historia Natural, 2: 249-287.

Corbet, G.B. \& Hill, J.E. 1991. A world list of mammalian species. 243 pp. Oxford University Press.

Daubenton, L.J.M. 1759. Mémoire sur les chauve-souris. Histoire de l'Académie Royale des Sciences, 1759: 374-398.

Dobson, G.E. 1878. Catalogue of the Chiroptera in the collection of the British Museum. xlii, 567 pp., 30 pls. British Museum, London. 
Ellerman, J.R. \& Morrison-Scott, T.C.S. 1951. Checklist of Palaearctic and Indian mammals 1758 to 1946.810 pp. British Museum (Natural History), London.

Geoffroy Saint-Hilaire, E. 1803. Catalogue des mammifêres du Muséum National d'Histoire Naturelle. 272 pp. Paris.

Gray, J.E. 1843. List of the specimens of Mammalia in the collection of the British Museum. xxviii, 216 pp. British Museum, London.

Jones, G. 1997. Acoustic signals and speciation: the roles of natural and sexual selection in the evolution of cryptic species. Advances in the Study of Behaviour, 26: 317-354.

Jones, G. \& Parijs, S.M. van. 1993. Bimodal echolocation in pipistrelle bats: are cryptic species present? Proceedings of the Royal Society of London, 251B: 119-125.

Kalko, E.K.V. 1995. Insect pursuit, prey capture and echolocation in pipistrelle bats (Microchiroptera). Animal Behaviour, 50: 861-880.

Kaup, J.J. 1829. Skizzirte Entwickelungs-Geschichte und Natürliches System der Europäischen Thierwelt ... Erster Thiel (welcher die Vogelsäugethiere und Vögel, nebst Andeutung der Enstehung der letzteren aus Amphibien enthält). xii, 203 pp. Darmstadt \& Leipzig.

Leach, W.E. 1825. Description of the Vespertilio pygmaeus, a new species, recently discovered in Devonshire by Dr. Leach. Zoological Journal, 1(4): 559-561.

Park, K.J., Altringham, J.D. \& Jones, G. 1996. Assortative roosting in the two phonic types of Pipistrellus pipistrellus during the mating season. Proceedings of the Royal Society of London, 263B: 1495-1499.

Pennant, T. 1771. Synopsis of quadrupeds. xxv, 382 pp. Chester.

Schreber, J.C.D. von. 1774. Die Säugthiere in Abbildungen nach der Natur mit Beschreibungen, vol. 1. 190 pp., 62 pls. Weigel, Leipzig.

Stebbings, R.E. \& Griffith, F. 1986. Distribution and status of bats in Europe. 142 pp. Institute of Terrestrial Ecology, Huntingdon.

Vaughan, N., Jones, G. \& Harris, S. 1997. Habitat use by bats (Chiroptera) assessed by means of a broad-band acoustic method. Journal of Applied Ecology, 34: 716-730.

Comments on this case are invited for publication (subject to editing) in the Bulletin; they should be sent to the Executive Secretary, I.C.Z.N., c/o The Natural History Museum, Cromwell Road, London SW7 5BD, U.K. (e-mail: iczn@nhm.ac.uk). 

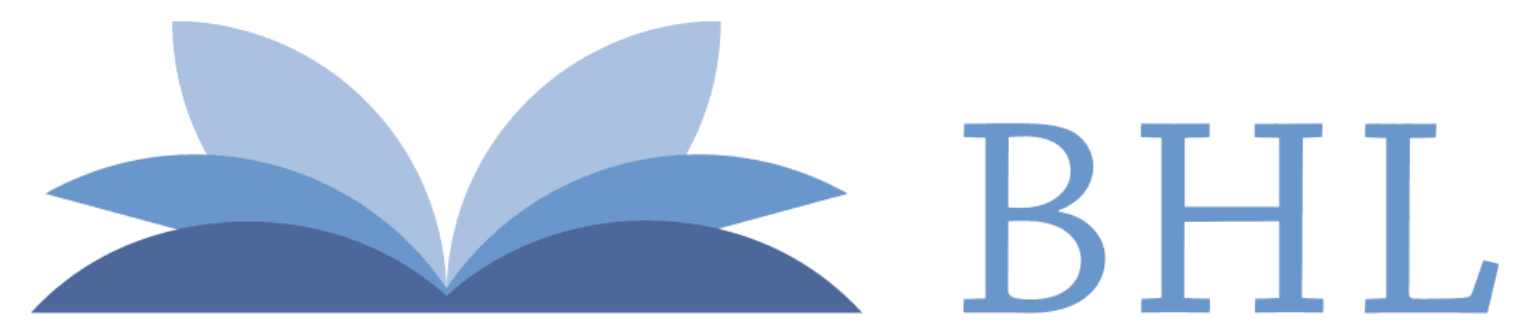

\section{Biodiversity Heritage Library}

Jones, G and Barratt, E M. 1999. "Vespertilio pipistrellus Schreber, 1774 and V. pygmaeus Leach, 1825 (currently Pipistrellus pipistrellus and P. pygmaeus; Mammalia, Chiroptera): proposed designation of neotypes." The Bulletin of zoological nomenclature 56, 182-186. https://doi.org/10.5962/bhl.part.23065.

View This Item Online: $\underline{\text { https://www.biodiversitylibrary.org/item/45032 }}$

DOI: https://doi.org/10.5962/bhl.part.23065

Permalink: https://www.biodiversitylibrary.org/partpdf/23065

\section{Holding Institution}

Natural History Museum Library, London

\section{Sponsored by}

Natural History Museum Library, London

\section{Copyright \& Reuse}

Copyright Status: In copyright. Digitized with the permission of the rights holder.

License: http://creativecommons.org/licenses/by-nc-sa/3.0/

Rights: https://biodiversitylibrary.org/permissions

This document was created from content at the Biodiversity Heritage Library, the world's largest open access digital library for biodiversity literature and archives. Visit BHL at https://www.biodiversitylibrary.org. 